\title{
A NEW BRACHYPTEROUS MESEPIPSOCUS (PSOCODEA: 'PSOCOPTERA': EPIPSOCIDAE) FROM BOLIVIA
}

\author{
Alfonso N. García Aldrete \\ Departamento de Zoología, Instituto de Biología, Universidad Nacional Autónoma de México, \\ Apartado Postal 70-153, 04510 México, D. F., MÉXICO. \\ e-mail: anga@ibiologia.unam.mx
}

García Aldrete, A. N. 2009. A new brachypterous Mesepipsocus (Psocodea: 'Psocoptera': Epipsocidae) from Bolivia. Acta Zoológica Mexicana (n. s.), 25(2): 383-386.

ABSTRACT. A new species of brachypterous Mesepipsocus, the first species of this genus recorded in Bolivia, is here described and illustrated. It has caeciliusid wing venation, and the gonapophyses lack V1. The type is deposited in the National Collection of Insects, Instituto de Biología, UNAM, México City.

Key words: Epipsocetae, Epipsocidae, Mesepipsocus, Bolivia, new species.

García Aldrete, A. N. 2009. Un nuevo Mesepipsocus braquíptero (Psocodea: 'Psocoptera': Epipsocidae) de Bolivia. Acta Zoologica Mexicana (n. s.), 25(2): 383-386.

RESUMEN. Una nueva especie braquíptera de Mesepipsocus, es aquí descrita e ilustrada. Es la primera especie del género que se conoce en Bolivia. La venación es caeciliúsida, y las gonapófises carecen de V1. El tipo está depositado en la Colección Nacional de Insectos, Instituto de Biología, UNAM, México, D. F.

Palabras clave: Epipsocetae, Epipsocidae, Mesepipsocus, Bolivia, nueva especie.

\section{INTRODUCTION}

The knowledge of the Bolivian Psocoptera is rather limited. Lienhard \& Smithers (2002), cite only 26 species in 19 genera occurring in the country. García Aldrete (2004 a, and b), described the genera Ianthorntonia, with five species, and Rogojiella, with one species. I have done some psocid collecting in Bolivia recently and have identified at least 27 genera in addition to those recorded by Lienhard \& Smithers (2002). In this paper I describe and illustrate one species of Mesepipsocus, the first known in Bolivia, peculiar in being brachypterous and in having caeciliusid forewing venation; it is assigned in Mesepipsocus by having V2 +3 strongly heeled anteriorly, and by lacking V1.

Recibido: 20/11/2008; aceptado: 03/02/2009. 


\section{MATERIAL AND METHODS}

The only specimen available for study, was dissected in $80 \%$ ethyl alcohol, and its parts (head, right legs and wings, and genitalia), were mounted on a slide in Canada balsam. Before dissecting, the specimen was placed in $80 \%$ ethyl alcohol under a dissecting microscope illuminated with white, cold light at $80 \mathrm{X}$ to record coloration. Measurements, given in İm, were taken with a filar micrometer with a measuring unit of $1.36 \mu \mathrm{m}$ for wings and $0.53 \mu \mathrm{m}$ for other parts. Abbreviations of parts measured are the following: FW, HW: length of fore- and hind- wings, F, T, t1 and t2: length of femur, tibia and tarsomeres 1 and 2 of right hind leg, Mx4: length of fourth segment of right maxillary palp, f1...fn: length of flagellomeres $1 \ldots \mathrm{n}$ of right antenna, IO, D and d: minimum distance between compound eyes, antero-posterior diameter and transverse diameter of right compound eye, all in dorsal view of head, PO: d/D. The type is deposited in the National Insect Collection, Instituto de Biología, Universidad Nacional Autónoma de México, Mexico City (Coden: CNIN).

\section{Family Epipsocidae}

\section{Mesepipsocus bolivianus n. sp. ( $q)$.}

(Figs. 1-8)

Color. Body reddish brown. Compound eyes black, ocelli hyaline, with ochre centripetal crescents. Scape and pedicel pale brown; f1 almost white, except for brown distal fourth, rest of the flagellum brown.

Morphology. Forewing brachypterous, elytriform, with venation caeciliusid, pterostigma wider in the middle, Rs and $\mathrm{M}$ almost straight, areola postica elongate, posteriorly almost reaching M3; hindwing represented by a small winglet (Fig. 1). Lacinial tip (Fig. 6), with outer cusp broad, bearing five denticles. Subgenital plate (Fig. 2), wide, narrow, setose; posterior border obtusely convex. Gonapophyses (Fig. 7): robust, V2 a short, setose lobe on side of V3; distal process slender, with a field of microspines distally; V2+3 with a short, stout heel anteriorly. Ninth sternum unpigmented, with spermapore posteriorly (Fig. 7). Paraproct (Fig. 5), almost semicircular, setose as illustrated; sensory field small, almost circular, with seven trichobothria on basal rosettes. Epiproct (Fig. 5), straight anteriorly, rounded posteriorly, with a group of three mesal setae near anterior border, and other setae as illustrated, mostly on distal half.

Measurements. FW: 1,149, HW: 200, Mx4: 216, F: 752, T: 1,126, t1: 498, t2: 167, ctt1: 2, IO: 448, D: 187, d: 134, IO/D: 2.39, PO: 0.71.

Type locality. BOLIVIA. Cochabamba. $72 \mathrm{~km}$ NE Cochabamba, on Hwy. to Villa Tunari, 2,954 m., $17^{\circ} 10.513$ 'S: $65^{\circ} 54.026^{\prime}$ W. 9.IV.2004. Beating dead fern fronds and vegetation on rock wall on roadside. Holotype $q$. A. N. García Aldrete.

Etymology. The specific name refers to the country of origin of this species. 

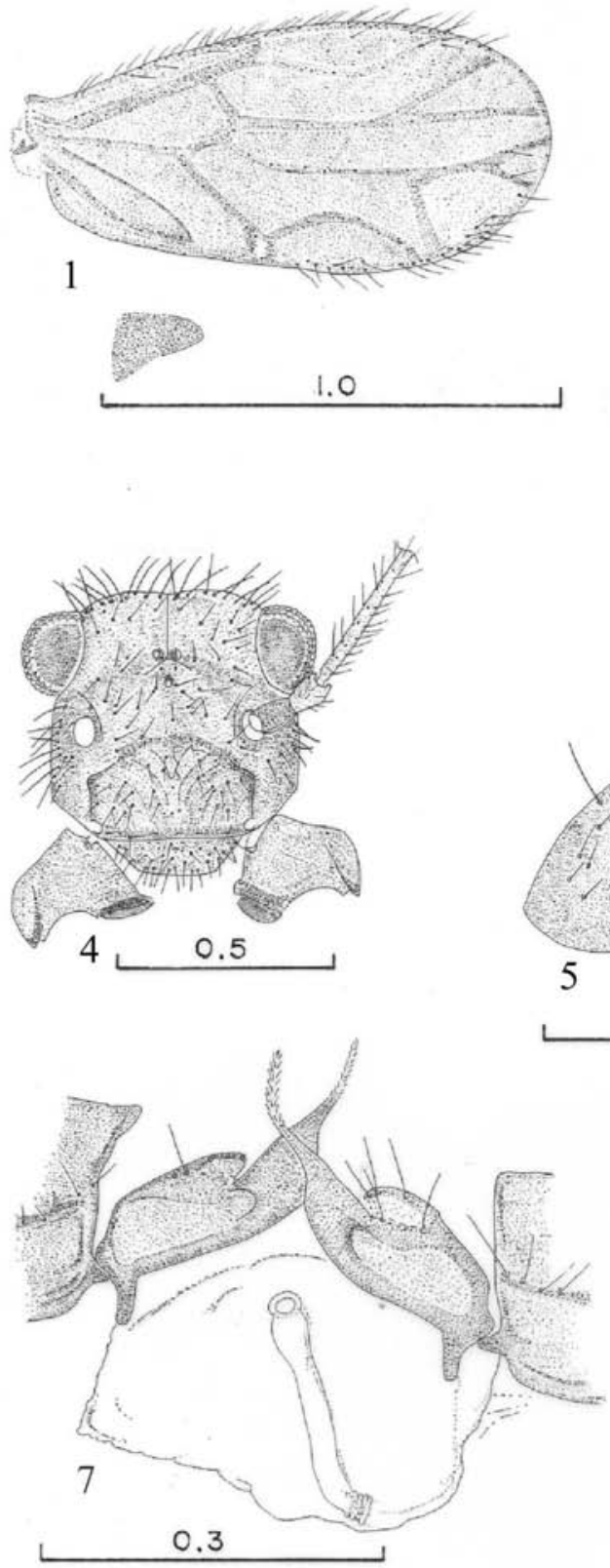
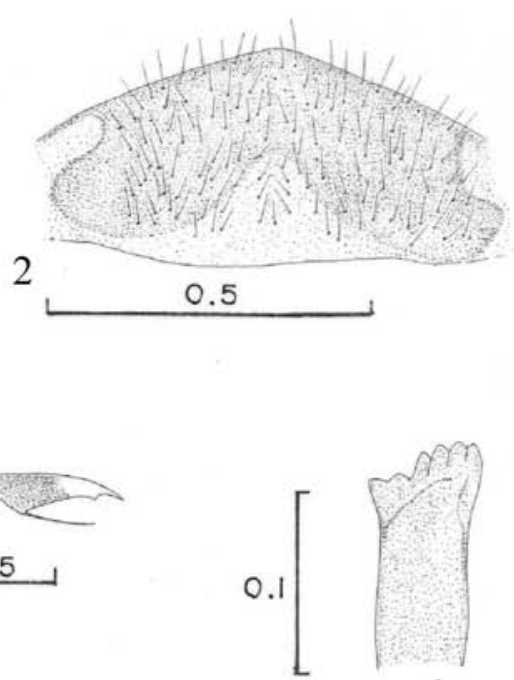

6
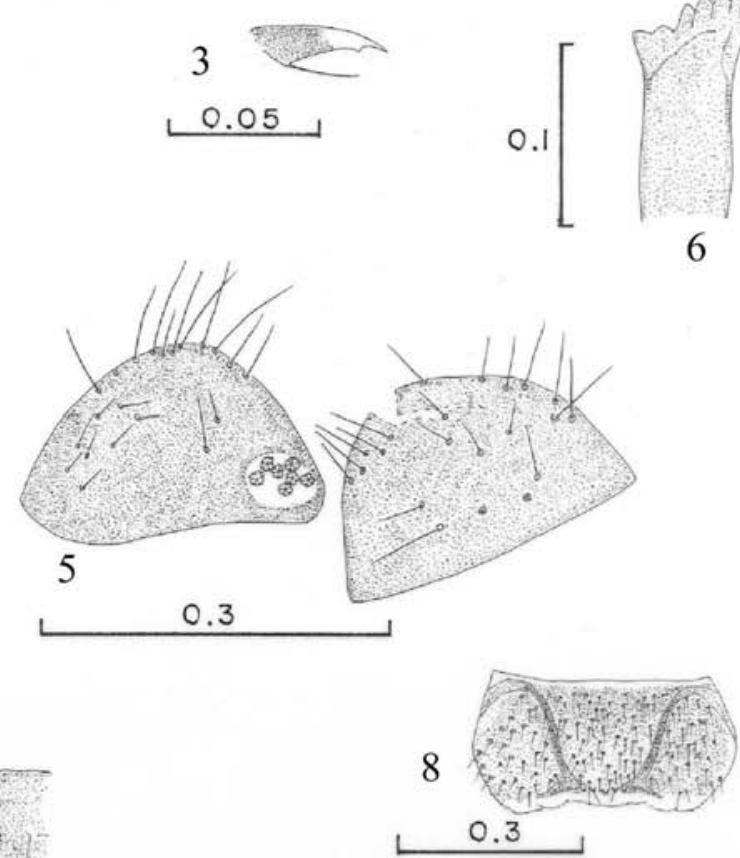

Figures 1-8. Mesepipsocus bolivianus n. sp. (q). 1. Fore- and hind- wings. 2. Subgenital plate.

3. Pretarsal claw. 4. Front view of head. 5. Right paraproct and epiproct. 6. Lacinial tip.

7. Gonapophyses and ninth sternum. 8. Labrum. Scales in $\mathrm{mm}$. 
Comments. As presently known, Mesepipsocus needs revision (Casasola González 2006). M. andrewsi (Turner), possibly M. antillanus (Banks), M. broadheadi (Turner), and $M$. icarus (Banks), constitute a taxon of generic level, distinct from Mesepipsocus, on basis of the genital structure of the males. The same applies to $M$. proctus (New \& Thornton), which presents an autapomorphic epiproct, completely different from the epiproct shown by the other species of Mesepipsocus. Of the 25 remaining species, 12 present caeciliusid venation, including the amber fossil species $M$. clarus Mockford, eight species have forewing M dichotomously branched, resulting in four $\mathrm{M}$ veins, four species have $\mathrm{M}$ with five branches, and one species is brachypterous, with forewing venation not well defined; in all, V2+3 has a distinct anterior heel, and V1 is missing, although a few undescribed South American species have a short V1.

Brachyptery is not common in Mesepipsocus, and in general in the genera of Epipsocetae, only the Brazilian M. brunellus (New 1972), from Mato Grosso, shows the same brachypterous plan as M. bolivianus, with forewing brachypterous and hindwing much reduced, represented only by a winglet. In the whole of the genera of Epipsocetae, only Epipsocus quurcus Roesler (1940), from Santa Catharina, Brazil has a brachypterous form, and the Chinese Liratepipsocus jinghongicus Li Fasheng (2002) is also brachypterous.

ACKNOWLEDGMENTS. Felipe Villegas (Instituto de Biología, UNAM), prepared the plate of illustrations. Psocoptera collecting in Bolivia in 2004 was possible through partial financing from Instituto de Biología, UNAM.

\section{LITERATURE CITED}

Casasola González, J. A. 2006. Phylogenetic relationships of the genera of Epipsocetae (Psocoptera: Psocomorpha). Zootaxa 1194: 1-32.

García Aldrete, A. N. 2004 a. A new genus of Bolivian Epipsocidae (Psocoptera). Journal of the New York Entomological Society 112 (4): 217-220.

García Aldrete, A. N. 2004 b. A new epipsocid genus (Psocoptera: Epipsocidae) from Bolivia. Pp. 99113. In: García Aldrete, A. N., C. Lienhard \& E. L. Mockford (Eds.). Thorntoniana. A commemorative volume for Ian W. B. Thornton. Publicaciones Especiales 20. Instituto de Biología, Universidad Nacional Autónoma de México. México, D. F.

Li Fasheng. 2002. Psocoptera of China. Vol. I. (In Chinese). Science Press, Beijing, China. 1092 pp.

Lienhard, C. \& C. N. Smithers. 2002. Psocoptera (Insecta). World Catalogue and Bibliography. Instrumenta Biodiversitatis V. Muséum d'histoire naturelle, Genève, Switzerland. 745 pp.

New, T. R. 1972. Some Epipsocetae (Psocoptera) from Central Brazil. Transactions of the Royal Entomological Society of London 123 (4): 455-497.

Roesler, R. 1940. Neue und wenig bekannte Copeognathengattungen. II. Zoologischer Anzeiger 130 $(1 / 2): 1-25$. 